\title{
Oxidation of Hydroxylamine by Waugh Type POM, Enneamolybdomanganate(IV) ion (A Kinetic and Mechanistic Study)
}

\author{
J. N. BARGE and G. S. GOKAVI* \\ Department of Chemistry, Shivaji University, Kolhapur-416 004, Maharashtra, India. \\ ${ }^{*}$ Corresponding author E-mail: gsgokavi52@gmail.com \\ http://dx.doi.org/10.13005/ojc/330554
}

(Received: March 03, 2017; Accepted: July 30 , 2017)

\begin{abstract}
ABSTARCT
The reaction between hydroxyl amine and Waugh-type polyoxometalate, enneamolybdomanganate(IV), was investigated under pseudo-first-order condition in aqueous perchloric acid. The product of the reaction was nitrous oxide as determined by studying the stoichiometry which requires one mol of oxidant per mole of hydroxylamine. The rate of reaction increases as hydrogen ion and oxidant, enneamolybdomanganate(IV), concentrations increase, while it remains unchanged as the hydroxylamine concentration is altered. The oxidant exists in both protonated and unprotonated form under the reaction conditions and both are active. The hydroxyl amine remains in the protonated form and reacts with the active forms of the oxidant with different rate constants. The proposed mechanism, in accordance with the kinetic results obtained, involves reaction between hydroxyl amine and oxidant in a slow step. The rate law derived as per the proposed mechanism is also verified kinetically. Change in ionic strength and solvent polarity did not affect the rate of the reaction while activation parameters were calculated by studying the reaction at different temperatures
\end{abstract}

Keywords: Polyoxometalate oxidation, Reaction mechanism, Enneamolybdomanganate, Hydroxylamine.

\section{INTRODUCTION}

Hydroxylamine is an intermediate between nitrous oxide and ammonia, it can be oxidized to nitrous oxide and reduced to ammonia'. Its redox chemistry also has biological importance as in nitrification it is oxidized by the enzyme hydroxylamine oxidoreductase(HAO) obtained from nitrosomonas europaea bacteria to nitrite ${ }^{2-5}$.
Hydroxylamine can be obtained back through reduction of nitrite by another enzyme nitrite reductase ${ }^{6}$. Therefore, hydroxylamine is an important intermediate if the oxidation reduction transformation of biological nitrification reaction. The primary mechanism of oxidation of hydroxylamine to nitrous oxide ${ }^{7-9}$ by the $\mathrm{HAO}$ is the reduction of its $\mathrm{Fe}^{\mathrm{III}}$ containing redox centre to $\mathrm{Fe}^{\mathrm{II}}$. Hydroxylamine is also used in organic synthesis ${ }^{10}$ in combination 
with oxidant like iodate for conversion of alcohols to corresponding carbonyl compounds selectively. The mechanism proposed for oxidation of alcohols involve formation of a nitrosated intermediate as a result of formation of nitric oxide. Substituted hydroxylamine are also used as a ligand for metals ${ }^{1}$ and metal oxides ${ }^{11}$ for formation of oxime complexes. These oxime complexes are used as catalysts for oxidation of alcohols, sulphides, amines and olefins to epoxide ${ }^{11}$.

Polyoxometalates(POM) are the stable anionic metal oxygen clusters with or without a heteroatom either at the centre or at the surface. These POMs with discrete structure resemble enzymes in their activities specifically the oxidative transformations ${ }^{12-14}$. The properties of the hetero atom either at the centre in POM or at the surface of a lacunary POM can be altered so that they can be used for specific catalysis. The POMs can be utilized as the electron transfer, oxygen transfer or radical pathways as well as solid acids ${ }^{13,15-16}$. Due to such versatility of POM they are considered as model metalloenzymes in biologically analogous oxidations. Therefore, interaction between the redox active metal centres in a POM with hydroxylamine another biologically important simple molecule in nitrification reaction is of mechanistic interest.

It has been also noticed that the $\mathrm{Mn}^{\mathrm{III}}$ and $\mathrm{Fe}^{\mathrm{III}}$ substituted POMs have shown good catalytic activity in transferring oxygen from idosobenzene to either alkene or alkane ${ }^{17-18}$. The activity is anaologous to metallophorphyrins and the $\mathrm{Mn}^{\mathrm{III}}$-POM was found to be more active than that of the Fe $\mathrm{Fe}^{\mathrm{III}}$-POM. Therefore, we have considered a Waugh type POM, enneamolybdomanganate(IV), as an oxidant to understand its reactivity towards hydroxylamine. The oxidant used in the present study is composed of central $\mathrm{Mn}^{\mathrm{IV}} \mathrm{O}_{6}$ unit surrounded by nine $\mathrm{MoO}_{6}$ octahedra. The redox potential of the $\mathrm{Mn}^{\mathrm{IV}} / \mathrm{Mn}^{\mathrm{II}}$ couple ${ }^{19}$ in the POM is about $1.035 \mathrm{~V}$ which is considerably lower that the value $^{20}$ of $1.51 \mathrm{~V}$ for free couple thus making it as a mild oxidizing agent. Since the oxidation of hydroxylamine by $\mathrm{HAO}$ involves $\mathrm{Fe}^{\mathrm{III}} / \mathrm{Fe}^{\mathrm{II}}$ redox couple in its mechanism we investigated its oxidation by enneamolybdomanganate(IV) which also involve $\mathrm{Mn}^{\mathrm{IV} / \mathrm{Mn}}{ }^{\mathrm{I}}$ redox couple ${ }^{21}$.

\section{EXPERIMENTAL}

Materials

Reagent grade chemicals and doubledistilled water was used to prepare the solutions required.A known amount of hydroxylamine hydrochloride (S. D. Fine-Chem Ltd.) was dissolved in double-distilled water every day to obtain its stock solution. A known volume of perchloric acid was diluted with double-distilled water to get its solution. The ammonium salt of $\mathrm{Mn}^{\mathrm{IV}}$ complex, $\left(\mathrm{NH}_{4}\right)_{6}\left[\mathrm{Mn}^{\mathrm{iv}} \mathrm{Mo}_{9} \mathrm{O}_{32}\right]$ was synthesized according to reported method ${ }^{22}$. The synthesized polyoxometalate was characterized by FTIR and AAS to understand the structure and formula of the compound ${ }^{23-24}$. The reaction was followed by measuring the absorbance of the reaction mixture using Elico SL177 spectrophotometer.

\section{Kinetic Measurements}

While studying the reaction, pseudo-first order conditions were maintained in which $\left[\mathrm{NH}_{2} \mathrm{OH}\right]$ was in large excess over [oxidant] in a thermostat kept at $25 \pm 0.1^{\circ} \mathrm{C}$. To initiate the reaction, known volumes of the earlier thermostated solutions of $\mathrm{NH}_{2} \mathrm{OH},\left(\mathrm{NH}_{4}\right)_{6}\left[\mathrm{Mn}^{\mathrm{IV}} \mathrm{Mo}_{9} \mathrm{O}_{32}\right]$ and perchloric acid were mixed. The advancement of the reaction was monitored spectrophotometrically at $468 \mathrm{~nm}$ $\left(\varepsilon=360 \pm 2 \mathrm{dm}^{3} \mathrm{~mol}^{-1} \mathrm{~cm}^{-1}\right.$ ) by measuring the change in absorbance of oxidant upto $80 \%$ completion of the reaction. From the slope of plot of log [oxidant] versus time the pseudo-first order rate constants were calculated which were found to be reproducible within $\pm 5 \%$. Reaction mixtures containing constant $\left[\mathrm{Mn}^{\mathrm{IV}} \mathrm{Mo}_{9} \mathrm{O}_{32}\right]^{6-}$ of $2.0 \times 10^{-3}$ and $\left[\mathrm{NH}_{2} \mathrm{OH}\right]$ from $0.5 \times 10^{-4}$ to $2.5 \times 10^{-4} \mathrm{~mol} \mathrm{dm}^{-3}$ were prepared and analysed for unreacted oxidant after $24 \mathrm{~h}$ to determine the stoichiometry. For each mol of $\mathrm{NH}_{2} \mathrm{OH}$ in the reaction mixture one mole of oxidant was consumed. Therefore, the reaction stoichiometry is $1 ; 1 \mathrm{~mol}$ of $\mathrm{NH}_{2} \mathrm{OH}$ per mole of oxidant which indicate nitrous oxide as the product according to the equation 1. A similar stoichiometry for the oxidation of hydroxylamine by $\mathrm{Fe}(\mathrm{III}),\left[\mathrm{CoW}_{12} \mathrm{O}_{40}\right]^{5-}$, $\mathrm{AuCl}_{4}^{-}$and peroxydisulphate ${ }^{25-28}$ was reported.

$\mathrm{H}_{6}\left[\mathrm{Mn}^{\mathrm{IV}} \mathrm{Mo}_{9} \mathrm{O}_{32}\right]+\mathrm{NH}_{2} \mathrm{OH} \rightarrow \mathrm{H}_{8}\left[\mathrm{Mn}^{\mathrm{II}} \mathrm{Mo}_{9} \mathrm{O}_{32}\right]+\frac{1}{2} \mathrm{~N}_{2} \mathrm{O}+\mathrm{H}^{+}$ 


\section{RESULTS AND DISCUSSION}

The formation of free radical in a reaction is examined by studying the reaction by adding acrylonitrile which is free radical scavenger. The addition of acrylonitrile between 10 to $40 \% \mathrm{~V} / \mathrm{V}$ to the reaction mixture did not alter the rate constant nor there was a precipitation due to the polymerization of acrylonitrile. Therefore, from the absence of precipitate due to polymerization and no change in the rate constant it can be concluded that formation of free radical intervention is not occurring in the reaction. The effect of added molybdate, $\mathrm{MnSO} 4$ and the ionic strength also did not affect the rate of the reaction. In order to find the order in [oxidant] a plots of log [oxidant] against time for the [oxidant] between $0.36 \times 10^{-3}$ to $3.6 \mathrm{x}$ $10^{-3} \mathrm{~mol} \mathrm{dm}^{-3}$ were examined and all the plots were linear upto more than $93 \%$ of the reaction and the pseudo-first-order rate constants are also constant (Table 1). The constancy in rate constants as [oxidant] varies and the linearity of pseudo-first -order plots show that the order in [oxidant] is one. Similarly the constancy of the pseudo-first-order rate constants (Table 1 ) as $[\mathrm{NH} 2 \mathrm{OH}]$ changes from $5.0 \times 10^{-3}$ to $5.0 \times 10^{-2} \mathrm{~mol} \mathrm{dm}^{-3}$ at a constant [oxidant] of $1.5 \times 10-3 \mathrm{~mol} \mathrm{dm}-3$ shows the order of one in $[\mathrm{NH} 2 \mathrm{OH}]$. The concentration of perchloric acid was varied between 0.05 and $0.5 \mathrm{~mol} \mathrm{dm}^{-3}$ to understand the dependence of reaction on the $\left[\mathrm{H}^{+}\right]$. The reaction is catalysed (Table 2) by $[\mathrm{H}+]$ and the order in $\left[\mathrm{H}^{+}\right]$ was found to be less than one (0.5). Therefore, a graph of pseudo-first-order rate constants, kobs, against $\left[\mathrm{H}^{+}\right]$was plotted and found to be linear (Fig.1) with an intercept indicating that the reaction follows $\left[\mathrm{H}^{+}\right]$dependent and independent paths. The variation in ionic strength and solvent polarity were

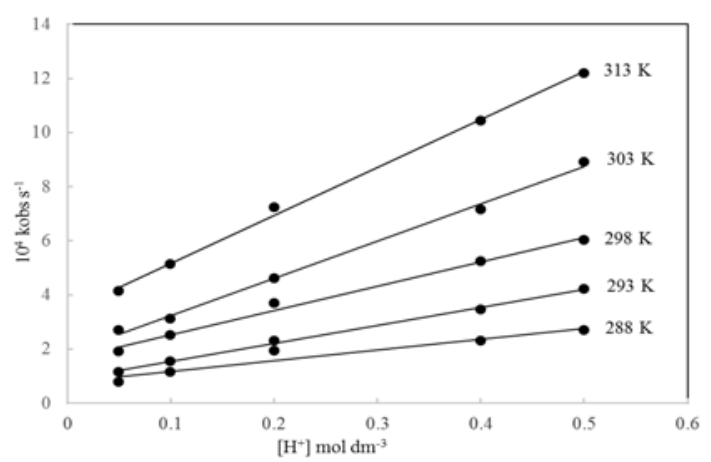

Fig.1. Plot of $\mathrm{k}_{\mathrm{obs}}$ against $\left[\mathrm{H}^{+}\right]$at different temperatures.

(Conditions as in Table 2). studied at $25^{\circ} \mathrm{C}$ by sodium perchlorate and acetonitrile. Variation in both ionic strength and solvent polarity did not affect the reaction.

The UV-VIS spectrum of enneamolybdomanganate(IV) anion shows a charge transfer absorption band at $468 \mathrm{~nm}$ which is characteristic of the MnIV ion ${ }^{29}$ due to $\mathrm{A}_{2 \mathrm{~g}} \rightarrow{ }^{4} \mathrm{~T}_{2 \mathrm{~g}}$ transition. The UV-VIS spectrum of this anion shows two isobestic points due to the protonation ${ }^{22}$. The absorption band at $468 \mathrm{~nm}$ shifts when there is change in the environment around the MnIV ion ${ }^{29}$. Therefore, when the reaction mixture containing both the reactants is examined spectrophotometrically, the isosbestic points at 435 and $522 \mathrm{~nm}$ remain

Table. 1:Effect of concentration of enneamolybdomanganate(IV) and hydroxylamine on the rate of reaction at $25^{\circ} \mathrm{C}$

\begin{tabular}{lcc}
\hline $\begin{array}{l}\mathbf{1 0}\left[\mathrm{NH}^{2} \mathrm{OH}\right] \\
\mathbf{m o l ~ d m}^{-3}\end{array}$ & $\begin{array}{c}\mathbf{1 0}^{3}\left[\mathrm{MnIVMo}_{9} \mathrm{O}_{32}\right]^{6}- \\
\mathbf{~ m o l ~ d m}^{-3}\end{array}$ & $\mathbf{1 0}^{4}$ kobs s$^{-1}$ \\
\hline 1.0 & 0.36 & 1.01 \\
1.0 & 1.1 & 2.96 \\
1.0 & 1.5 & 3.80 \\
1.0 & 2.7 & 6.91 \\
1.0 & 3.6 & 9.98 \\
0.5 & 1.5 & 3.80 \\
1.0 & 1.5 & 3.83 \\
1.5 & 1.5 & 3.90 \\
2.0 & 1.5 & 3.91 \\
5.0 & 1.5 & 3.85 \\
\hline
\end{tabular}

$\left[\mathrm{HClO}_{4}\right]=0.2 \mathrm{~mol} \mathrm{dm}^{-3}, \mathrm{I}=0.3 \mathrm{~mol} \mathrm{dm}^{-3}$.

unchanged as well as the intensity of both the peaks decrease. If hydroxylamine interacts with the oxygen atoms of the $\mathrm{MnO}_{6}$ octahedra of the oxidant then the band at $468 \mathrm{~nm}$ would have been reappeared. Instead, the existence of isosbestic point in the UV-VIS spectrum of the reaction mixture and decrease in intensity is due to absence of interaction of hydroxylamine through oxygen atoms bound to $\mathrm{MnO}_{6}$ octahedra and also absence of formation of a strong complex between the reactants.

The coordination chemistry of hydroxylamine has been rarely studied except as a transition state in its transition metal or metal catalysed oxidations 30 . Considering the probable binding sites of hydroxylamine would be either the 
$\mathrm{N}$ or the $\mathrm{O}$ atom various metal complexes of $\mathrm{N}, \mathrm{N}$-bis(2-\{pyrid-2-ylethyl\}) hydroxylamine were synthesized 1. The complexation was found to occur through neutral amine group of hydroxylamine as a binding site and these complexes were also reduced by the metal ions. Therefore, the binding site in the hydroxylamine is the neutral, unprotonated, amine group. The present study was carried out in acidic solutions and since the pK of amine group 30 is 5.9 it will be in the protonated form. Therefore, the complex formation through amine group in the present study is not feasible. Since, the hydroxylamine is completely protonated at all hydrogen ion concentration used in the present study, the effect of hydrogen ion concentration on the rate will not be due to the change in the reactive species of the reductant. On the other hand, the oxidant, $\left[\mathrm{MnMo}_{9} \mathrm{O}_{32}\right]^{6-}$, exists in the protonated, $\mathrm{H}_{6}\left[\mathrm{MnMo}_{9} \mathrm{O}_{32}\right]$, form as evidenced by its UV-VIS spectra in acidic conditions and further dissociates to give $\mathrm{H}_{5}\left[\mathrm{MnMo}_{9} \mathrm{O}_{32}\right]$. Therefore, under the present reaction conditions, both $\mathrm{H}_{6}\left[\mathrm{MnMo}_{9} \mathrm{O}_{32}\right]$ and $\mathrm{H}_{5}$ [MnMo9O32]- are present in solution. The reaction follow a two term rate law with $\left[\mathrm{H}^{+}\right]$dependent and independent indicating( $\mathrm{Fig} 1$ ) both $\mathrm{H} 6\left[\mathrm{MnMo}_{9} \mathrm{O}_{32}\right]$ and H5[MnMo9O32]- are reactive species of the oxidant. Therefore, the mechanism considering both $\mathrm{H}_{6}\left[\mathrm{MnMo}_{9} \mathrm{O}_{32}\right]$ and $\mathrm{H}_{5}\left[\mathrm{MnMo}_{9} \mathrm{O}_{32}\right]$ - as active oxidant species and protonated hydroxylamine, $\mathrm{NH}_{3} \mathrm{OH}^{+}$, as the active reductant species can be represented as in Scheme I. According to Scheme I the rate law can be derived as follows.

The expression derived for the pseudofirst-order rate constant, kobs, as in equation 11 satisfy all the kinetic results obtained. In the expression 11, there is no term containing the concentrations of either $\left[\mathrm{Mn}^{2+}\right]$ and $\left[\mathrm{Mo}_{\mathrm{O}_{4}}{ }^{-}\right]$indicating that the polyoxometalate, $\left[\mathrm{MnMo}_{9} \mathrm{O}_{32}\right]^{6}$, remain intact before the reaction and after the reaction. Since, the effect of acrylonitrile did not form any precipitate and also did not affect the kobs values it can be concluded that the reaction did not involve a single electron transfer step. The reaction proposed in Scheme I proceeds through two paths one dependent on $\left[\mathrm{H}^{+}\right]$and the other independent of $\left[\mathrm{H}^{+}\right]$. The $\left[\mathrm{H}^{+}\right]$dependent path has the greater rate constant than that of the $\left[\mathrm{H}^{+}\right]$independent path as noticed from slope and intercept of Fig.1.The former major path involves a neutral species of the oxidant therefore, the change in ionic strength did not affect the reaction as noticed by studying the reaction at different sodium perchlorate ion concentrations. The rate law 11 can also be verified by plotting kobs against $\left[\mathrm{H}^{+}\right]$and which was found to be linear with an intercept (Fig.1) thus justifying the mechanism suggested. The effect of solvent polarity on the reaction was studied by varying the acetonitrile content in the reaction mixture. Since the major path of the reaction contains a neutral oxidant species again, as in case of ionic strength effect, the rate constant remain unaffected even after changing the solvent polarity. The polyoxometalates are outersphere oxidants and interaction between the hydroxylamine and $\left[\mathrm{MnMo}_{9} \mathrm{O}_{32}\right]^{6-}$ was also not noticed during the UV-VIS spectrophotometric examination of the reaction mixture. Therefore, the probable transition state in the present reaction is replacement of a water molecule of $\left[\mathrm{MnMo}_{9} \mathrm{O}_{32}\right]^{6-\text { by }}$ $\mathrm{NH}_{2} \mathrm{OH}^{+}$ion to form a precursor complex. Such precursor complex is rather loosely bound thus leading to moderate decrease in entropy of

Table. 2 : Effect of perchloric acid concentration on the rate of reaction

\begin{tabular}{|c|c|c|c|c|c|}
\hline \multirow{2}{*}{$\begin{array}{l}\text { Temperature } \\
\text { K }\end{array}$} & \multicolumn{5}{|c|}{$10^{4} \mathrm{kobs} \mathrm{s}^{-1}$ at } \\
\hline & $\begin{array}{c}{\left[\mathrm{H}^{+}\right]=0.05} \\
\mathrm{~mol} \mathrm{dm}\end{array}$ & $\begin{array}{c}{\left[\mathrm{H}^{+}\right]=0.1} \\
\mathrm{~mol} \mathrm{dm}^{-3}\end{array}$ & $\begin{array}{l}{\left[\mathrm{H}^{+}\right]=0.2} \\
\mathrm{~mol} \mathrm{dm}\end{array}$ & $\begin{array}{c}{\left[\mathrm{H}^{+}\right]=0.4} \\
\mathrm{~mol} \mathrm{dm}^{-3}\end{array}$ & $\begin{array}{c}{\left[\mathrm{H}^{+}\right]=0.5} \\
\mathrm{~mol} \mathrm{dm}\end{array}$ \\
\hline 288 & 0.77 & 1.15 & 1.92 & 2.30 & 2.69 \\
\hline 293 & 1.15 & 1.54 & 2.30 & 3.45 & 4.22 \\
\hline 298 & 1.90 & 2.50 & 3.68 & 5.24 & 6.03 \\
\hline 303 & 2.69 & 3.10 & 4.61 & 7.14 & 8.91 \\
\hline 313 & 4.14 & 5.13 & 7.23 & 10.4 & 12.2 \\
\hline
\end{tabular}

$10^{3}\left[\mathrm{Mn}^{\mathrm{IV}} \mathrm{Mo}_{9} \mathrm{O}_{32}\right]^{6-}=1.5 \mathrm{~mol} \mathrm{dm}^{-3}, 10^{2}\left[\mathrm{NH}_{2} \mathrm{OH}\right]=1.0 \mathrm{~mol} \mathrm{dm}^{-3}, \mathrm{I}=0.6 \mathrm{~mol} \mathrm{dm}^{-3}$. 


$$
\begin{aligned}
& \mathrm{H}_{6}\left[\mathrm{MnM}_{09} \mathrm{O}_{32}\right] \rightleftharpoons \mathrm{Ka}_{\mathrm{a}} \rightleftharpoons \mathrm{H}_{5}\left[\mathrm{MnMog}_{32}\right]^{-}+\mathrm{H}^{+} \\
& \mathrm{H}_{6}\left[\mathrm{MnMog}_{32}\right]+\mathrm{NH}_{3} \mathrm{OH}^{+} \longrightarrow \mathrm{kl}_{1} \longrightarrow \mathrm{H}_{8}\left[\mathrm{MnMog}_{32}\right]+\mathrm{HNO}+\mathrm{H}^{+} \\
& \mathrm{Hs}\left[\mathrm{MnNo9O}_{32}\right]^{-}+\mathrm{NH}_{3} \mathrm{OH}^{+} \underset{\mathrm{k}_{2}}{\stackrel{\mathrm{F}}{\longrightarrow}} \mathrm{H}_{8}\left[\mathrm{MnM}_{09} \mathrm{O}_{32}\right]+\mathrm{HNO} \\
& 2 \mathrm{HNO} \stackrel{\text { Fast }}{\longrightarrow} \mathrm{N}_{2} \mathrm{O}+\mathrm{H}_{2} \mathrm{O}
\end{aligned}
$$

Scheme 1

Rate $=\mathrm{k}_{1}\left[\mathrm{H}_{6}\left[\mathrm{MnMog}_{32}\right]\right]\left[\mathrm{NH}_{3} \mathrm{OH}^{+}\right]+\mathrm{k}_{2}\left[\mathrm{H}_{s}\left[\mathrm{MnMog} \mathrm{O}_{32}\right]^{-}\right]\left[\mathrm{NH}_{3} \mathrm{OH}^{+}\right]$

From equilibrium (2) of Scheme I we get for total $\left[\mathrm{H}_{6}\left[\mathrm{MnMog}_{9} \mathrm{O}_{32}\right]\right]$ as

$$
\begin{aligned}
& \left.\left[\mathrm{H}_{6}\left[\mathrm{MnMo}_{9} \mathrm{O}_{32}\right]\right]_{\mathrm{Tot} a 1}=\left[\mathrm{H}_{6} \mathrm{MnMog}_{32}\right]\right]_{\text {Free }}+\left[\mathrm{H}_{5}\left[\mathrm{MnMog}_{9} \mathrm{O}_{32}\right]^{-}\right] \\
& {\left[\mathrm{H}_{6}\left[\mathrm{MnMo}_{9} \mathrm{O}_{32}\right]\right]_{\text {Total }}=\left[\mathrm{H}_{6} \mathrm{MnMog}_{92}\right]_{\text {Free }}+\frac{\mathrm{Ka}\left[\mathrm{H}_{6}\left[\mathrm{MnMog}_{32}\right]\right]_{\text {Free }}}{\left[\mathrm{H}^{+}\right]}} \\
& {\left[\mathrm{H}_{6}\left[\mathrm{MnMog}_{32}\right]\right]_{\text {Total }}=\left[\mathrm{H}^{+}\right]\left[\mathrm{H}_{6} \mathrm{MnMog}_{92} \mathrm{O}_{32}\right]_{\text {Free }}+\mathrm{Ka}\left[\mathrm{H}_{6}\left[\mathrm{MnMog}_{32}\right]\right]_{\text {Fee }}}
\end{aligned}
$$

$\left[\mathrm{H}^{+}\right]$

$$
\begin{aligned}
& \left.\left[\mathrm{H}_{6}\left[\mathrm{MnMog}_{32}\right]\right]_{\text {Total }}=\left[\mathrm{H}_{6} \mathrm{MnMog}_{9} \mathrm{O}_{32}\right]\right]_{\text {Free }} \frac{\left(\left[\mathrm{H}^{+}\right]+\mathrm{Ka}\right)}{\left[\mathrm{H}^{+}\right]} \\
& \left.\left[\mathrm{H}_{6}\left[\mathrm{MnMog}_{32}\right]\right]_{\mathrm{Free}}=\left[\mathrm{H}^{+}\right]\left[\mathrm{H}_{6} \mathrm{MnMog}_{9} \mathrm{O}_{32}\right]\right] /\left(\left[\mathrm{H}^{+}\right]+\mathrm{Ka}\right) \\
& \left.\left[\mathrm{H}_{5}\left[\mathrm{MnMog}_{32}\right]^{-}\right]=\mathrm{K}_{\mathrm{a}}\left[\mathrm{H}_{6} \mathrm{MnMog}_{32}\right]\right]_{\mathrm{Free}}=\mathrm{K}_{\mathrm{a}}\left[\mathrm{H}_{6}\left[\mathrm{MnMog}_{32}\right]\right] /\left(\left[\mathrm{H}^{+}\right]+\mathrm{Ka}\right)
\end{aligned}
$$

Then from equations 6,8 and 9 we get

$$
\begin{aligned}
& \text { Rate }=\left[\mathrm{H}_{6}\left[\mathrm{MnMog}_{0_{32}}\right]\left[\mathrm{N} \mathrm{H}_{3} \mathrm{OH}^{+}\right]\left(\left(\mathrm{k}_{1}\left[\mathrm{H}^{+}\right]+\mathrm{k}_{2}\right) /\left(\left[\mathrm{H}^{+}\right]+\mathrm{K}_{\mathrm{a}}\right)\right\}\right. \\
& \mathrm{k}_{\mathrm{obs}}=\left(\mathrm{k}_{1}\left[\mathrm{H}^{+}\right]+\mathrm{k}_{2}\right) /\left(\left[\mathrm{H}^{+}\right]+\mathrm{K}_{\mathrm{a}}\right)
\end{aligned}
$$

activation as noticed in the present study( Table 3). The energy of activation of the $\left[\mathrm{H}^{+}\right]$dependent path, in which the active oxidant species is neutral, is higher than that of $\left[\mathrm{H}^{+}\right]$independent path, in which it is in the anionic form due to dissociation. In the latter path the collision between both the reactants is more feasible as they are oppositely charged thus reducing the energy of activation than that in the former path as one of them is neutral which requires comparatively more energy of activation ( Table 3). Since, the hydroxylamine is in the protonated from the formation of precursor.complex between two oppositely charged reactants is more favoured with more decrease in activation entropy than when one of them is neutral with less decrease in entropy of activation ( Table 3). 
Table. 3: Activation parameters for the $\left[\mathrm{H}^{+}\right]$ dependent and independent term of rate law. (Conditions as in Table 2)

\begin{tabular}{|c|c|c|}
\hline $\begin{array}{l}\text { Activation } \\
\text { parameter }\end{array}$ & $\begin{array}{c}{\left[\mathrm{H}^{+}\right] \text {dependent }} \\
\text { term }\end{array}$ & $\begin{array}{c}\left.\mathrm{H}^{+}\right] \text {independent } \\
\text { term }\end{array}$ \\
\hline Ea kJmol-1 & $56.6 \pm 2$ & $45.9 \pm 2$ \\
\hline $\mathrm{DH} \# \mathrm{kJmol}^{-1}$ & $42.0 \pm 2$ & $43.7+2$ \\
\hline -DS\# J K-1 $\mathrm{mol}^{-1}$ & $121.4 \pm 5$ & $-172.0 \pm 5$ \\
\hline DG\# kJmol-1 & $78.2 \pm 2$ & $94.9 \pm 2$ \\
\hline
\end{tabular}

\section{CONCLUSIONS}

The reaction between enneamolybdomanganate(IV) and hydroxylamine in aqueous perchloric acid was found occur by direct twoelectron transfer step without formation of precursor complex. The hydroxylamine under the experimental conditions remains completely protonated while both protonated and unprotonated forms of enneamolybdomanganate (IV) are the active oxidant species thus making the reaction to be catalysed by hydrogen ion concentration. The rate law consists of two terms containing hydrogen dependent and independent terms. The activation parameters for both hydrogen dependent and independent paths of the reaction were determined. The product of the reaction was found to be nitrous oxide.

\section{ACKNOWLEDGEMENTS}

GSG acknowledge the facilities procured under DST-FIST and UGC-SAP by the Department.

\section{REFERENCES}

1. Belock, C. W.; Cetin, A.; Barone, N. V.; Ziegler, C.J. Inorg. Chem. 2008, 47, $7114-7120$.

2. Rees, M. K. Biochemistry. 1968, 7(1), 353 - 366.

3. Rees, M.K. Biochemistry. 1968, 7(1) 366 - 372.

4. Hendrich, M. P.; Petasis, D.; Arciero, D. M.; Hooper, A. B. J. Am. Chem. Soc. 2001, 123(13), 2997- 3005.

5. Kurnikov, I. V.; Ratner, M. A.; Pacheco, A. A. Biochemistry. 2005, 44(6), 1856 - 1863.

6. Crane, B. R.; Siegel, L. M.; Getzoff, E. D. Biochemistry. 1997, 36(40), 12101 - 12119.

7. Moir, J.W.B.;Wehrrritz, J.; Spiro, S.; Richardson, D. J. Biochem. J. 1996, 319, 823 - 827.

8. Cabail, Z. M.; Kostera, J.; Pacheco, A. A. Inorg. Chem. 2005, 44, 225 - 231.

9. Fernandez, M. L.; Estrin, D. A.; Bari, S. E. J. Inorg. Biochem. 2008, 102, 1523 - 1530.

10. Majee, A.; Kundu,S. K.; Santra, S.; Hajra, A. Tetrahedron Lett. 2012, 53, 4433 - 4435.

11. Gharah, N.; Chakraborty, S.; Mukherjee, A. K.; Bhattacharyya, R. Inorg. Chem. Acta . 2009, 362, 1089 - 1100.

12. Carneiro, A.; Abreu, A.; Evtuguin, D.V.; Neto,C.P.; Guebitz, G.; Paulo, A. C. J. Mol Cat. B. 2000, 9, 293 - 295.

13. Galli, C.; Gentili, P.; Pontes, A. S. N.; Gamelas, J. A. F.; Evtuguin, D. V. New J. Chem, 2007, 31, 1461- 1467.

14. Wang, J.; Han, D.; Wang, X.; Qi, B.; Zhao, M. Biosens. Bioelectron. 2012, 36, 18 - 21.

15. Mizuno, N.; Misono, M. Chem Rev. 1998, 98,
$199-218$.

16. Kozhevnikov, I.V. Chem. Rev. 1998, 98, 171 - 198.

17. Hill, C. L.; Brown, Jr., R. B. J. Am. Chem. Soc. 1986, 108, 536 - 538.

18. Mansuy, D.; Bartoli, J. F.; Battioni, P.; Lyon, D. K.; Finke, R. G. J. Am. Chem. Soc. 1991, 113, 7222 - 7226.

19. Dunne, S.J.;Burns, R.C.;Hambley, T.W.;Lawrance, G. A. Aust. J. Chem. 1992, 45, 685-693.

20. Lurie J., Handbookof Analytical Chemistry, Mir Publishers, Moscow, 1975.

21. Nipani,S. V.; Gurame, V. M.; Gokavi, G. S. Inorg. Chem. Commun. 2011, 14, 1102- 1106.

22. Baker, L. C. W.; Weakly, T. R. J. J. Inorg. Nucl. Chem. 1966, 28, 447- 454.

23. Gurame, V. M.; Supale, A. R.; Gokavi, G. S. Amino Acids, 2010, 38, 789 - 795.

24. Gurame, V. M.; Gokavi, G. S. Polyhedron, 2008, 27, 1905 - 1910.

25. Bengtsson, G.; Fronaeus, S.; Bengtsson-Kloo, L. J. Chem. Soc., Dalton Trans. 2002, 2548 - 2552.

26. Goyal, B.; Prakash, A.; Mehrotra, R. N. Indian J. Chem. 1999, 38A, 541- 546.

27. Soni, V.; Mehrotra, R. N. Transition Met. Chem. 2003, 28, 893 - 898.

28. Swaroop, R.; Gupta, Y. K. J. Inorg. Nucl. Chem. 1974, 36, 169 - 174.

29. Saito, A.; Tomari, H.; Choppin, G. R. Inorg. Chim. Acta. 1997, 258, 145 - 153.

30. Biliski, P.; Motten, A. G.; Biliska, M.; Chignell, C. F. Photochem. Photobiol. 1993, 58, 11- 18. 